\title{
A Practical and Clinical Application of the Septoplasty
}

\author{
Byung Hoon Ahn \\ Department of Otorhinolaryngology, School of Medicine, Keimyung University, Daegu, Korea
}

\section{비중격 교정술의 실제와 응용}

\author{
안 병 훈 \\ 계명대학교 의과대학 이비인후과학교실
}

\author{
Received April 4, 2014 \\ Accepted August 16, 2014 \\ Address for correspondence \\ Byung Hoon Ahn, MD, PhD \\ Department of Otorhinolaryngology, \\ School of Medicine, \\ Keimyung University, \\ 56 Dalseong-ro, Jung-gu, \\ Daegu 700-712, Korea \\ Tel $+82-53-250-7718$ \\ Fax $+82-53-256-0325$ \\ E-mail bhahn@dsmc.or.kr
}

A nasal septal deviation is a condition that should be handled as a disease entity only when a patient complaints intractable nasal stuffiness or decreased quality of life. Also a surgeon should diagnose a various cause of the nasal obstruction including static and dynamic collapse of the nasal valve. Although septoplasty is most commonly performed operation to relieve the nasal obstruction, it is sometimes very difficult and cumbersome because of a variety of septal pathology. A surgeon should be aware of the specific condition of patients and should apply the tailored techniques to correct each condition. This review could provide a detailed and practical information at each steps of the septoplasty, also gives various tips to remind at the operation room and outpatient clinic. Recent papers regarding septoplasty techniques, tips and pearls, complications are reviewed and my personal recommendations with tiny tips are provided also.

Korean J Otorhinolaryngol-Head Neck Surg 2015;58(2):79-87

Key Words Nasal septum $\cdot$ Nasal valve $\cdot$ Septoplasty $\cdot$ Tips.

\section{서 론}

비 폐색을 주소로 내원하는 환자들에서 비중격 만곡증은 매우 흔한 변형이며, 여러 가지 적응증으로 수술적 치료를 선 택하게 된다. 비중격 교정술은 비과 영역에서 비염수술, 부비 동 내시경수술과 함께 매우 흔히 시행되는 수술로 과거에는 전 공의들이 비교적 일찍 접해 볼 수 있는 수술이었으나 현재는 그 술기의 다양성과 외비 성형술이 동시에 시행되는 경우가 있 어 직접 시행하기가 힘든 현실이다. 비중격 교정술(또는 성형 술)은 단순히 변형된 만곡 부위의 절제에서부터 비중격 연골 의 체외교정술(extracorporeal reconstruction)까지 다양한 술기를 알고 접근해야 하고, 제한된 공간에서 연골의 변형이 심 한 경우는 그 교정이 매우 까다로운 수술 중의 하나로 생각된 다. 비중격 교정술을 시행한 이후에도 비폐색이 생기는 경우는 여러 가지 요인에 의해 발생하게 되는데, 종물 또는 비용과 같 은 비강내 다른 요인을 간과한 경우, 알러지와 같은 점막 부종 이 동반 또는 악화된 경우, 비 밸브의 문제를 놓치거나 교정이
안 된 경우, 가장 문제가 되는 폐색부위의 교정에 너무 보존적 이거나 과소평가한 경우, 수술은 잘 시행되었으나 이후 연골의 위치변화 또는 뒤틀림이 생긴 경우이다. 이 중에서도 내, 외비 밸브에 가장 영향을 주는 부위의 비중격 교정이 불충분했던 경우가 수술자체에 의한 가장 많은 요인으로 생각된다. ${ }^{1-3)}$

비중격의 해부 및 비중격 만곡증의 분류 및 수술 전 마취 방 법은 이미 많이 다루어져 있어서 생략하고, 실제 환자의 선택 에서 최근의 비중격 교정술의 보조 술기와 함께 수술장에서 유의할 점들과 실제 응용할 수 있는 수술적 술기들을 기술하 고자 한다.

\section{환자의 선택과 상담}

비중격의 변형을 주소로 내원하였을 때 다양한 원인의 적응 증이 있다. 여기서 환자의 비폐색감은 매우 다양하게 표현되고 실제로 비중격 만곡증의 교정으로 증상호전을 달성할 수 있 는가는 비강 통기도 검사나 비강 압력계 등의 객관적인 비폐색 
의 증명과 함께 병력상의 다양한 원인 인자들을 함께 치료전 략으로 두는 것이 바람직하다. 저자는 환자에게 비중격 만곡증 이 비강내에 보이는 “변형 자체 또는 현상”이지 반드시 "질환" 이 아님을 설명하고, 비폐색을 유발하는 많은 원인 중의 하나 임을 주지시킨다. 심한 비중격의 만곡이 가장 중요한 주된 원 인이더라도 먼저 다양한 내과적인 치료를 먼저 권유한다. 최 근 재조명되고 있는 기능적 비폐색감에 연관된 비 밸브(nasal valve)에 대한 설명과 검사를 시행하여야 환자의 비폐색감에 대한 충분한 상담과 교정을 할 수 있다.,4) 수술 전 비강내 소견 을 보여주면서 상담을 시행하는 경우 환자에게 절대적 수직으 로 비중격이 교정된다는 환상은 심어주지 않는 것이 필요하다. 저자는 환자의 만곡된 부위의 변형을 설명하면서 현재보다 만 곡된 각도를 현저히 줄여서 비호흡이 호전된다는 설명을 하 고, 실제로 술자도 수술장에서 완전히 곧은 비중격을 얻으려 는 노력은 하지만 목표가 돼서는 안 될 것으로 생각된다.

최근에는 비중격 수술과 동시에 시행되는 비성형 수술에 대 한 상담을 많이 하는데, 환자들 중 일부는 비중격 수술로 외비 의 모양도 바로 교정되는 것으로 오인하는 환자도 있어 상담이 필요하며, 수술 후 안비변형에 대해서는 민감한 사안이므로 미리 환자의 외비 배부의 모양과 굴곡 정도, 함몰 여부를 미리 확인하고 기술해두는 것이 중요하다. 또한 수술 이후 관리와 약 2주간의 술 후 부종 또는 치유 기간에 대한 설명도 미리 해 두는 것이 수술 후 즉각적인 호전을 기대하는 환상을 없앨 수 있다.

\section{Tips}

1) 환자의 주소가 비폐색감일 때 어느 정도의 비중격 만곡 증을 발견하면 다른 원인을 찾는 데 다소 소홀해지므로 비중 격 만곡증 이외의 다른 원인을 찾는 것에도 집중하여야 한다.

2) 비중격 교정술로 얻을 수 있는 것과 수술적 한계를 미리 설명하여야 하고 술자도 인식하여야 한다.

3) 비 배부 변형에 대한 술 전 상태 기술과 술 후 관리에 대 해 상담한다.

\section{기본적인 술 전 검사}

과거의 이비인후과의는 비경으로 비강을 초진하는 것이 기 본이지만 비경을 이용하여 검사를 시행할 때는 비경으로 이미 외비공 및 연골, 비전정의 변형을 유발하면서 검사를 하고 있 다는 개념을 꼭 명심하여야 한다. 그러므로 먼저 환자의 진찰 은 광원만을 이용하여 육안으로 외비 모양과 비공의 상태, 외 비 변형 등을 관찰하는데 이때 여러 가지 외비 변형과 함께 조 용히 숨을 내쉴 때와 강하게 공기를 흡입할 때의 비익과 외비
의 함몰이 있는지 여부도 관찰하여 외비연골의 지지력을 미리 파악하는 것도 진단에 필수적이다. 이후에 비내시경을 이용하 여 전반적인 비강내 점막 및 비갑개 상태 등을 확인하여 부비 동염 및 비용 등의 추가적인 비폐색 원인을 찾는다. 마지막으 로 3차원적인 비중격의 상태를 파악하기 위해 비경을 이용하 여 최종적인 진단에 이르게 된다. 비강 수축제를 이용하여 환 자의 주관적 증상 변화를 보는 것은 하비갑개 수술 또는 약물 치료에 대한 부가적 진단을 가능하게 하므로 추가적으로 시행 하기도 한다.

비 밸브에 대해서 과거에는 Cottle 검사법으로 주관적인 환 자의 비폐색감의 호전을 예측했지만, 본 검사는 너무 과도하 게 비현실적으로 뺨을 외측으로 당겨서 나타날 수 있는 '가 양 성' 또는 비 밸브 유착 또는 절골술 후 상악골의 과도한 내측 화로 인한 '가 음성' 소견을 보일 수 있어 그 해석에 주의를 요 한다. ${ }^{3,5)}$ 외비 및 내비 밸브에 대한 검사는 modified Cottle 검 사가 유용한데, 이는 면봉 또는 끝이 부드러운 큐렛 또는 겸자 등을 이용하여 간편히 검사할 수 있다는 장점이 있다. 기구 끝 을 외부 및 내부 비 밸브 부위에 대고 가볍게 들어 올리거나 지지를 하고, 평소의 주관적인 비폐색감과 비교를 하는 것인데, 특히 흡기시 비 외측연골의 약화로 비익이 함몰되는 환자에서 는 코로 강한 흡기를 시키면서 호전여부를 파악해보는 것이 진단에 도움이 된다. 이때에도 너무 비현실적인 강한 지지는 '가 양성' 소견을 보이므로 육안적으로 외비가 너무 변형되지 않게 가볍게 지지하면서 환자의 증세 호전 여부를 파악하는 것이 중요하다. ${ }^{3,5)}$ 코 끝이 너무 쳐져 비순각이 90도 이하일 때 에는 가볍게 코 끝을 들어올려 환자의 증세 변화를 물어보는 것도 추가적인 외비 성형술이 도움이 될 수 있는지의 여부를 판단하는 데 도움이 된다. 외비 변형 중 비주의 하연이 과도하 게 넓고 두터워 비폐색이 있는 경우도 있으므로 이때는 겸자 를 이용하여 가볍게 내측으로 조여줄 때 증상의 호전이 있으 면 내각조임술을 고려하기도 한다. ${ }^{6}$ 이밖에 비폐색을 동반하 는 외비 변형으로는 높은 비배부와 긴 코, 좁고 틈새같은 비 공, 약한 상부 외비연골인 “긴장성 코(tension nose)", 내비밸브 함몰 및 폐색, 역 V자 변형을 보이는 “코를 잡은 모양(pinched nose)", 수직으로 위치한 아래 외비 연골 비공연이 약화, 안쪽 함몰 소견인 “괄호 모양 코(parenthesis nose)"가 있으므로 미 리 외비 변형을 동시에 교정하는 것도 염두에 두고 상담을 시 행한다. ${ }^{3)}$

\section{Tips}

1) 육안 검사, 비경 검사, 비내시경 검사를 모두 시행하여 비 폐색의 원인을 찾고자 노력한다.

2) 비폐색을 동반하는 외비 변형을 함께 진단하여야 한다. 
3) 구조 변형에 의한 정적인(static) 비폐색과 함께 숨을 들이 쉴 때 구조의 약화로 발생되는 동적(dynamic collapse)인 비 폐색감을 함께 인지해야 한다.

\section{수 술술기}

전통적인 Cottle's maxilla-premaxilla approach가 가장 기 본적인 접근법으로 절개(incision)-노출(exposure)-분리/가동 화(separation/mobilization)-교정(correction)-고정(fixation) 순서로 진행되는데 최근에는 비내시경을 이용하여 비중격 후 반부 및 세밀한 국소부위의 절제 또는 교정에 이용되기도 한 다. 특히 비내시경은 전공의 또는 학생들의 교육에 필수적으 로 수술의 전 과정을 보여줄 수 있으나, 전반적인 비중격 상태 를 판단 또는 술 중 교정 정도를 파악해야 하는 전체적인 삼 차원적인 결정이 요구될 때는 광원하에 육안으로 진행하여야 하므로 두 방법을 함께 병행하는 것이 바람직하겠다. ${ }^{2,7,8)}$ 그 외에 내시경을 이용한 비중격 교정술의 장점은 다양한 수술 에 적용할 수 있고 동시에 시행할 수 있다는 점이다. 특히 비중 격 돌기나 비중격 후방에 국한된 만곡증, 비중격 만곡증의 재 수술 등에 유용하다. 단점으로는 내시경 장비가 필요하고 양 손을 사용할 수 없으며, 출혈시 수술을 진행하기 어렵고, 미측 연골의 조작이 용이하지 않은 단점이 있다.,9)

모든 수술에 있어 기구의 다양성과 능숙한 조작은 매우 중 요한데, 비중격 교정술에 필요한 수술기구로는 비경(nasal speculum)에서부터 점막을 거상하는 거상기(cottle, Freer elevator), 골 절단 겸자(bone biting/cutting forceps), 비갑개 절제 가위(conchotomy scissors)까지 다앙한데, 특히 비경은 길이 와 모양에 따라 종류별로 구비하고 잘 다루어야 비중격 수술 에 있어 편리성과 효용성을 높일 수 있다. 전반적인 비강의 상 태관찰에서 사용하는 하트만 비경, 초기 절개시에 유용한 끝 부분이 작은 비경, 노출과 박리시에는 끝이 길고 가는 중비경, 서골의 끝 부분을 잘 노출시킬 수 있는 장비경을 준비하고 시 기에 따라 적절한 비경으로 점막을 견인하여야 좋은 시야를 얻 을 수 있다(Fig. 1). 거상기중, 특히 Cottle knife/elevator는 항 상 끝을 날카롭게 유지하여야 연골막을 절개 또는 거상하기 에 유용하므로 항상 날카롭게 유지하여야 한다(Fig. 2).

\section{절개(Incision)}

오른손잡이 술자는 주로 반 관통(hemitransfixion) 절개를 15 번 blade를 사용하여 연골의 좌측 미부에 가하게 된다. 이 때 반대측 비전정에 거즈를 일정 양 충전하여 연골 미부를 절 개하는 방향으로 밀어주면 좀 더 절개하기가 쉬워지며 비경을 든 좌측 손 검지 또는 중지로 미부 연골을 좌측으로 부가적으
로 밀면서 절개를 가하면 도움이 된다. 또한 수술칼을 최대한 짧게 잡고 우측 중지로 단단히 지지하면 안정성을 부가하여 세 밀한 절개가 가능하다(Fig. 3). 절개를 너무 연골에 깊게 시행 하면 또 다른 연골의 절개와 손상을 가져오므로 연부조직과 연골막 두께만큼 2 3회 얕은 절개로 연골막 하면인 수술면 (surgical plane)을 찾게 되는데, 초심자는 숙달되는 데 경험 이 필요하여 한 번의 절개로 수술면을 확보하려고 해서는 안

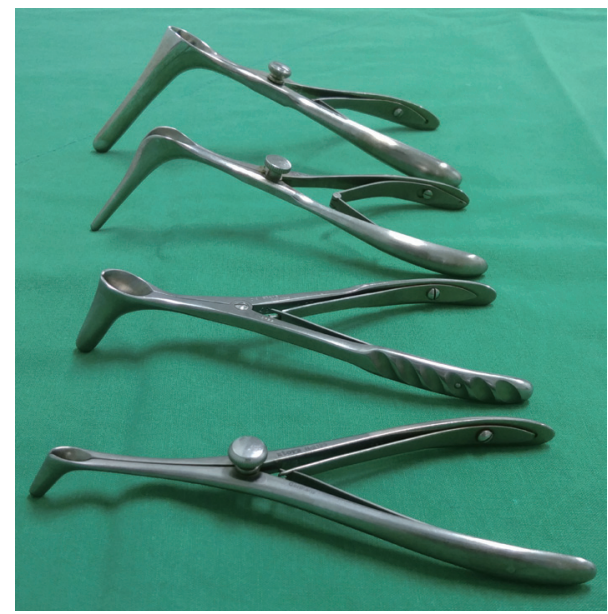

Fig. 1. Various nasal speculums used to dilate the nostril and surgical tunnels.

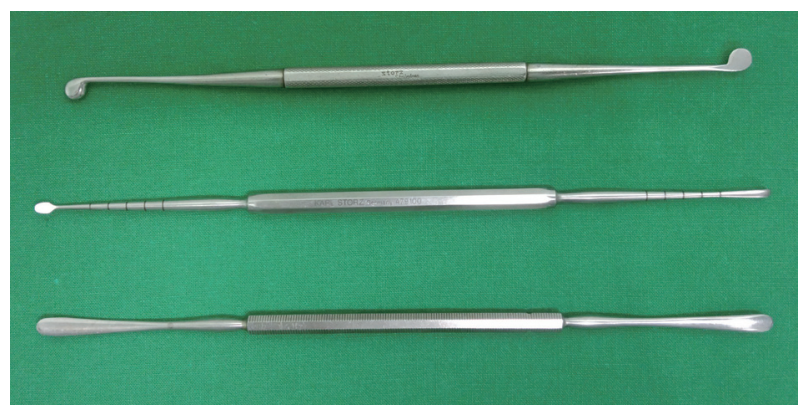

Fig. 2. Various mucosal elevators to dissect the mucoperichondrium and periosteum.

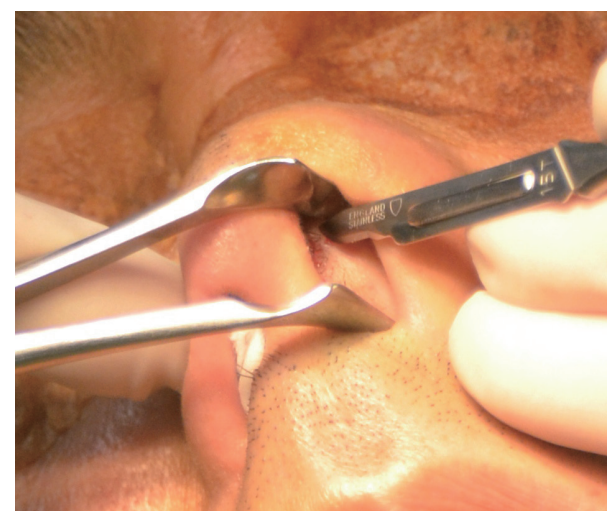

Fig. 3. When a hemitransfixion incision is made, packing of gauze strips at the opposite vestibule and gentle pushing with finger toward incision site is very helpful. 
된다. 끝이 예리한 Freer elevator 또는 Cottle knife를 이용하 여 연골막을 들어올리는데, 수술면이 의심이 되면 다시 한 번 15번 blade를 사용하여 매우 얕은 절개를 하고 다시 연골막을 거상하려고 노력한다. 저자는 끝이 날카로운 iris scissors를 사용하여 피부 절개 후 절개선을 따라 기구 끝을 연골에 대고 수 차례 연부조직을 박리하고 연골막까지 포켓을 만들어 수 술면에 도달한다(Fig. 4). 전방과 하부 터널을 만드는 방식의 접근법을 위해서 L자형의 절개가 비전정 하연에까지 시행할 수 있으나 숙달이 되면 1자형의 미부 절개만으로도 상악골능 을 박리하는 데 큰 어려움이 없다. 절개 후의 연부조직 출혈은 양극성 소작기를 이용하여 지혈하고 좁은 수술시야를 방해하 지 않도록 한다.

\section{Tips}

1) 절개가 경사지지 않게 수직으로 시행되어야 하고 비공연 의 피부를 실수로 절개하지 않도록 유의한다.

2) 절개연을 너무 작게 하면 충분한 시야를 확보하지 못하 고 무리한 견인으로 부가적인 조직의 손상을 가져오므로, 절 개창을 작게만 하려는 노력은 하지 않는다.

3) 한 번 절개로 연골막 하연에 도달하지 말고, 연부조직 박 리 후 추가적인 절개로 확인한다.

\section{노출(Exposure)}

비중격의 가장 미부 연골막은 연조직으로 인해 박리와 노 출이 힘들어 어떤 경우 절개연의 다소 후방에서 수술면을 거 상하는 것이 도움이 된다. 적절한 수술면은 힘이 들지 않게 박 리가 되면서, 출혈이 없고, 창백한 연골의 확인과 함께 다소 기 구 끝에 느껴지는 거친 면으로 확인하는데, 투명하게 반짝거리 면서 혈관이 비치는 거상된 연골막 하연을 관찰하여 직접 확 인할 수도 있다. ${ }^{2,4)}$

사각연골의 면을 따라 후방으로 연골막을 거상하면 기구 끝에 느껴지는 다소 거칠고 딱딱한 골부가 느껴지는데, 골막

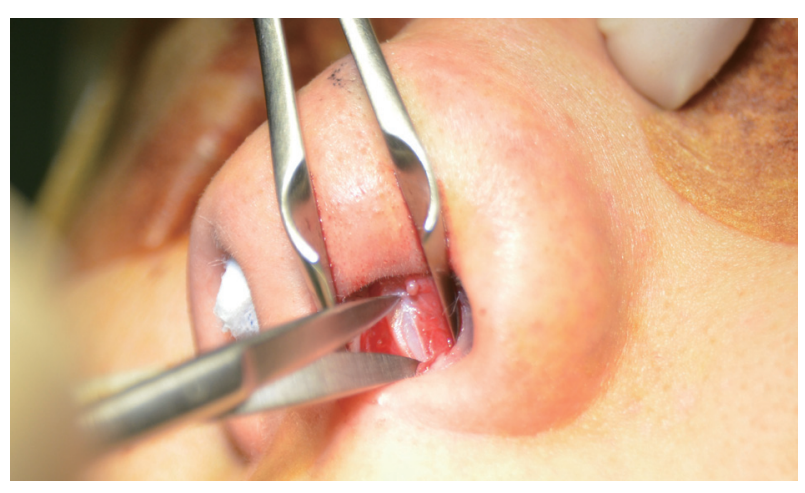

Fig. 4. Using iris scissors to incise the perichondrium is recommended not to harm the underlying cartilage.
의 거상은 더욱 쉽게 이루어진다. 이때 날카로운 비중격 능이 나 극(ridge, spur)을 덮고 있는 점막은 변형 부위의 상부와 하 부의 점막에 포켓을 만들듯이 평행하게 먼저 거상한 후, 포켓 을 통해 비갑개 절제가위 또는 osteotome을 이용하여 절골술 을 시행한 후, 겸자를 이용하여 골부를 골절시키고 정중선으 로 가동화시키면 능이나 극 부위의 점막을 거상하기 쉽다. 점 막을 거상하면서 양측의 점막이 손상되더라도 적절히 봉합해 주면 비중격 천공이 일어나지는 않지만 최대한 동시에 양측의 점막손상이 일어나지 않도록 유의해야 한다. 특히 비중격 능이 나 극부위를 거상할 때 선상으로 점막이 깨끗하게 손상이 일 어난 경우는 바르게 정렬해주고 4-0 chromic catgut으로 한 번 정도 봉합해 주면 잘 치유가 된다.

Tips

1) 연골막 하연인 수술면을 다소 전방에서 놓치더라도 연골 의 괴사가 일어나지는 않지만, 다소 박리가 힘들 때는 다시 한 번 수술 칼로 미세하게 연골 위를 절개하여 연골막을 거상하 도록 노력해야 한다.

2) 날카로운 비중격 능이나 극(ridge, spur)을 덮고 있는 점 막은 무리하게 박리하지 말고 미리 적절한 절골술로 가동화시 키면 점막을 찢지 않고 박리할 수 있다.

\section{분리 및 가동화(Separation/mobilization)}

충분히 거상된 수술면을 육안으로 확인하면서 사각연골과 사골수직판의 연결부위, 상악릉과의 연결을 무딘 거상기를 이 용하여 분리시킨다. 이때 반드시 L strut를 보존하기 위해 육 안으로 확인하여 상부 $1.5 \mathrm{~cm}$ 의 연결 부위는 보존하는 지점 다소 아래쪽부터 분리시킨다. ${ }^{47)}$ 연골과 골부의 접점을 무리하 게 분리시키려고 과도한 힘을 가하면 반대쪽 점막의 손상을 초래하므로 연골부에 연골을 1 2 $\mathrm{mm}$ 남기고 분리를 시도하 는 것이 용이할 수도 있다. 연골과 골부의 변형 정도에 따라 양 측의 점막을 모두 거상하고 수술을 시행하여도 점막의 괴사 는 오지 않으므로 연골막을 변형부위까지 충분히 거상하고 수 술을 시행한다. 반대쪽 점막의 거상은 연골-골부 접점에서부 터 반대쪽 골막을 들면서 만들고 역으로 상악릉을 따라 앞쪽 으로 진행할 수도 있고, 연골부의 변형이 심할 때는 연골 미부 부터 새로운 전방터널을 만들어 시행할 수도 있다. 골부의 교 정을 시행하기 전에 사골수직판을 먼저 비갑개 절제 가위로 수 평으로 절단시켜 놓으면 이후 수직판의 골 조직을 제거하면서 생기는 뒤틀리는 힘이 상부로 전달되는 것을 막을 수 있다.

Tips

1) 연골과 골부의 분리시 keystone area에 너무 접근하면, 
이 부위의 연골을 $1.5 \mathrm{~cm}$ 이상 보존하여도 술 후 안비변형이 생길 수 있으므로 주의한다.

2) 수술 중 중비경으로 수술면을 벌리면서 견인을 계속 시행 하면, 예측된 상부 $1.5 \mathrm{~cm}$ 의 연결 부위보다 더 분리가 발생하 여 드물지만, 술 후 배부 함몰 변형이 가능하므로 연골과 사골 의 수직판을 분리할 때 다소 예측지점 아래쪽부터 분리를 시 행한다.

\section{교정(Correction)}

비중격 교정술 이후에 재수술이 요구되는 경우, 가장 교정 이 불충분한 부위는 내비밸브에 영향을 주는 비배부의 연골 부위(92\%)와 골성 비중격의 전방부(사골 수직판, $79 \%$ )로 보 고된다. 다음으로 많은 부위는 비중격 전방부(72\%)로 외비밸 브에 영향을 주고 내비밸브를 좁힐 수도 있다.,2)

비중격 교정술에서 가장 중요한 과정은 교정 부분(septal reconstruction)인데 골부의 변형은 적절한 노출과 제거를 통해 용이하게 교정이 가능하다. 연골부의 교정에 있어 과거에는 오 목면에 수술칼로 절개(hatching)를 하거나 반대면에는 wedge 제거술을 하고 이후 바르게 교정되길 기대했으나, 최근의 수술 개념에는 연골의 탄성 회복력(elastic recoil)을 약화시키기 위 한 목적으로만 사용된다. 그 외에 보조적인 술식으로는 suture technique, septal batten graft, swinging door, cutting and suture technique 등이 소개되어 있고 극심한 만곡인 경우는 체외교정술이 수행된다. 연골부의 미부 또는 배부가 과도하게 만곡을 보이는 경우에는 외비의 변형을 동반하는 경우가 많아 외비성형술이 동시에 시행되는데, 이때는 단단한 비중격의 교 정과 지지가 외비의 결과에도 많은 영향을 끼치므로 더욱 주 의를 요하고 펼침 이식술(spreader graft) 등이 주로 비배부의 교정에 큰 도움을 주므로 동시에 시행되는 경우가 많다.

연골부의 교정에서 L 구조물(L strut)의 보존은 매우 중요하 며 적절한 너비라도 두께가 얇은 경우는 자가연골을 이용하여 오목면에 덧대어 주고 5-0 polydioxane(PDS) 봉합사를 이용 하여 보강을 해준 후 말단 하연은 반드시 전상악극에 단단히 봉합해 준다. 간혹 연골 미부에 연골을 추가로 보강해 줄 때 전 방 비중격이 너무 두꺼워서 비호흡을 방해하는 경우를 걱정하 지만 대부분은 일어나지 않는다. 연골 미부의 길이계측은 매 우 중요하여 연골을 곧게 펴서 전상악극에 긴장 없이 편안하게 놓여질 수 있게 과도한 연골은 세심히 다듬어 준다.

연골의 미부 만곡에는 여러 가지 술식이 사용될 수 있어 septal repositioning, spreader graft, wedging, scoring, morselizing, suture technique, tongue-in-groove technique, batten graft 등이 가능하고 변형이 극심할 때에는 체외교정술이 필요하다. 연골의 미부는 봉합이 용이하나 배부의 심한 만곡이
있는 경우는 봉합이 용이하지 않고 펼침이식술을 동시에 시행 해야 하는 경우도 있다. 연골부의 중반부에서 상부의 만곡은 매우 교정이 힘들어 여러 가지 방법이 제시되고 있는데, $\mathrm{L}$ 구조 물의 재건술, 연골부 scoring, 비중격 연골 보강술, 비중격 연장 이식술, 체외교정술 등이 있다.

Lee 등 ${ }^{10}$ 은 wedge 술식으로 좋은 결과를 보고하였는데, 극 심한 변형이 있는 경우 또는 연골의 흡수에 한계가 있으며, 연 골부와 골부의 두께에 따른 환자의 선택에 한계가 있다고 하 겠다. 고정 봉합 술식(anchoring suture technique)은 PDS 봉 합사를 이용하여 원하는 만큼의 장력을 주면서 연골자체에 mattress 봉합으로 사골 수직판에 고정하여 굴곡을 펴는 방법 또 는 일정부위를 상악극에 고정하는 방법으로 매우 유용한 술 식이다(Fig. 5). 특히 고정봉합은 안비의 합병증 없이 비배부의 조작이 가능하고, 비밸브 부위를 교정할 수 있으며, 외비 성형 술 접근법 등을 시행하지 않고서도 심한 만곡을 교정할 수 있 어 얼굴에 수술자국이 남지 않는 장점이 있다. 하지만 봉합사가 풀리거나 연부조직이 늘어나면서 정봉합의 기능을 충분히 하 지 못하는 경우 만곡이 다시 생길 수 있다는 단점이 있다.11)

비배부의 만곡이 동반된 경우는 결국 외비연골에 대한 교 정이 동시에 이루어져야 적절한 배부 연골의 교정이 가능하다. 상외비연골의 함몰이나 변형의 동반여부가 중요한데, 함몰이 없는 경우는 비중격 점막 양측을 모두 거상시켜 배부 연골과 연결된 비중격상부를 분리시키고 연골의 교정을 시행한 후 다 시 외비연골과 비중격을 고정하며, 필요에 따라 요측에 펼침이 식을 시행한다. 외비연골의 함몰이 있는 경우는 내비밸브의 함몰과 만곡방향에 따라 그 교정 술식이 다르게 요구된다. 내 비밸브의 함몰이 만곡의 반대측에 있을 때는 펼침이식을 요 측에 시행하고, 내비밸브의 함몰이 만곡쪽에 있을 때는 펼침 이식을 양측에 모두 시행하여야 적절한 교정이 가능하다." 심 한 비배부의 만곡 교정에는 사골 수직판을 지지대로 한 변형 mattress 봉합술로 부가적인 교정이 가능하나, 연골과 골부의 두께와 지지력, 수술의 난이도에 한계가 있을 수 있다. ${ }^{12)}$

술자가 가장 선호하는 방식은 연골부의 교정에서 L 구조물

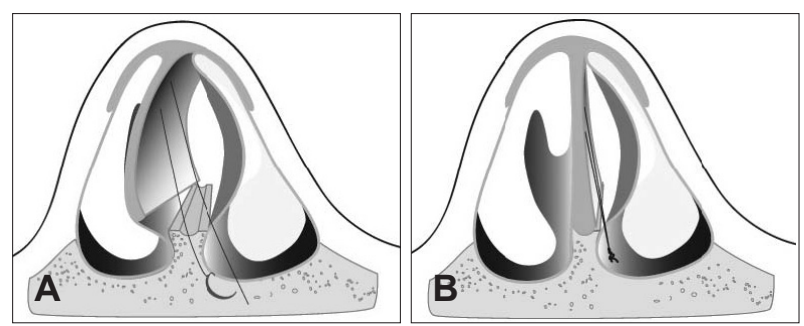

Fig. 5. Illustration of an anchoring suture technique. A needle is passed through the most concave site of septal cartilage (A), pulled and fixed (B) at the anterior maxillary spine or the overlying periosteum with proper tension to straighten the cartilage. Adapted from Song, et al. ${ }^{11)} \mathrm{J}$ Rhinol 2006;13(1):18-21. 
을 유지하고 잉여 연골 또는 사골 수직판의 일부를 덧대는 보강 이식술을 시행하여 연골부를 바로 펴 주는 방식으로, $1.5 \mathrm{~cm}$ 정도 의 충분한 L 구조물이 보존되어 있더라도 연골이 얇고 약하여 적절한 지지가 안 되는 경우에도 적응증이 된다. 한편 만곡된 연골부위가 두껍고 탄성이 많이 남아있는 경우는 연골의 자체 탄성 복원력을 제거하기 위하여 조심스럽게 scoring을 해 주고 보강이식술을 시행하는 것이 좋다(Fig. 6). 이때 강력한 지지는 일부 제거된 사골의 수직판에 미리 봉합사가 통과할 수 있도 록 구멍을 낸 후 만곡 부위에 덧대어 교정할 수도 있다.

비중격 보강 이식술의 문제점은 첫째, 일측의 점막 거상으로 도 가능하나 대개 양측의 전방 터널 점막을 거상해야 하며, 둘 째, 심하게 변형된 연골부는 잉여부위를 잘 다듬어 불충분한 교 정이 일어나지 않도록 주의해야 하고, 셋째, 연골미부가 전 상악 극에서 분리된 이후 적절히 교정이 이루지면 연골-보강이식 복합체를 단단히 다시 전상악극에 고정해야 한다. 넷째, 심한 변형으로 상외측 연골로부터 비중격을 분리시켜 교정이 필요 할 때에는 안비 변형을 방지하기 위하여 반드시 교정시에 이 식물이 상외측 연골에까지 도달하게 하여 고정한다. 다섯째, 변 형된 연골을 펴지게 하기 위해 먼저 연골에 교차절개가 요구 된다. 마지막으로 재수술시 연골이 부족한 경우에는 골부를 일 부 다듬어 보강 이식재료로 사용할 수 있다. 비중격 수술시 매 우 유용하게 시행되는 비중격 보강 이식술의 단점은 첫째, 비중 격 미부가 두꺼워질 수 있는데, 이 자체가 심각한 비 폐색을 유 발하지는 않는다. 둘째, 이식물로 골성 비중격을 이용할 때는 골 조직의 흡수가 가능하여 만곡이 재발할 수 있다. 셋째, 골연골 부위를 과도하게 분리하거나 연골미부를 과도하게 제거 한 경우는 경도의 안비가 생길 수 있어 주의가 요구된다. ${ }^{13,14)}$ Jang 등 ${ }^{15)}$ 은 상기 방법과 같이 연골을 보강이식을 하기 전 미 부 연골 일부에 절개를 시행하여 적절한 길이로 덧대어 고정 하거나 잉여연골을 덧대어 보강하는 술식을 소개하여 좋은 결과를 보고하였다(Fig. 7).
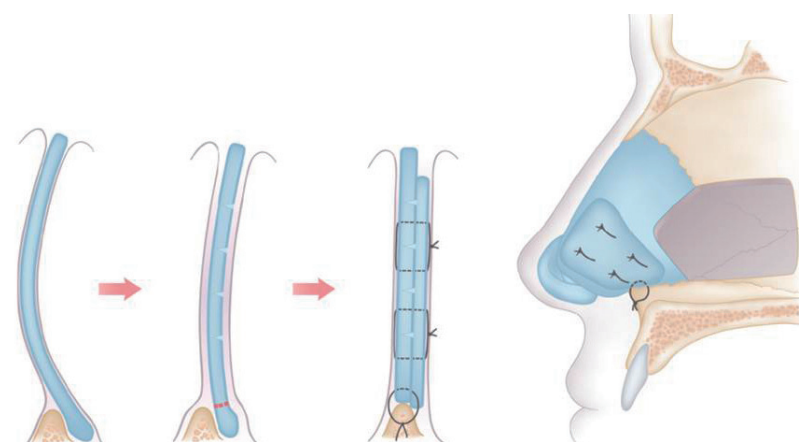

Fig. 6. Illustration of the batten graft on the left concave side to straighten the convexity of the caudal septum. Note that excess cartilage has been resected and the caudal septum-batten graft complex has been reattached to the anterior nasal spine. Adapted from Wee, et al. ${ }^{13)}$ Arch Otolaryngol Head Neck Surg 2012;138(5):457-61.
수술 전에는 비 배부의 상태를 기술해 놓는 것이 술 후 변형 에 대한 근거로 사용할 수 있으므로, 작은 함몰 또는 비혹에 대 한 상태를 인지하고 기록에 남겨두는 것이 좋다. 수술 후 비 배 부의 변형은 여러 가지 이유로 가능한데, 주로 과도한 연골의 절 제로 $\mathrm{L}$ 구조가 약화되는 것으로 전술한 바와 같이 연골의 두 께가 과도하게 얇은 경우는 $1.5 \mathrm{~cm}$ 를 보존하여도 추후 지지력 이 약해 비배부의 함몰이 일어나기도 한다. 또한 연골과 사골 수직판의 분리시에 너무 과도하게 상부로 연장되면 비골과의 연결부가 약해지는 결과를 초래하고, 사각연골을 전상악극에 서 분리하고 과도한 연골을 자르고 고정하더라도 너무 과도하 게 절제된 경우는 비배부의 연골이 전하연으로 당겨져 비배부 의 함몰이 일어나기도 한다. 적절한 L 구조의 지지가 약화되면 비배부의 함몰뿐만 아니라 비주와 비첨부의 변화도 술 후 즉 시 또는 시간이 지나서 상처의 구축으로 인해 야기될 수 있다. 즉 비배부와 외비의 변형은 다양한 형태로 나타나며 그에 따른 적절한 술기가 시행되어야 한다. 수술장에서 이러한 국한된 작 은 비배부 함몰을 발견한 경우는 수술장에서 바로 교정을 시 행하는 것이 권유되는데, 비중격 수술시 채취된 연골을 다듬어 추가적인 연골 간 절개를 통해 적합한 위치에 삽입해준다. 이외 에 비첨 및 외비의 변화도 수술시 또는 직후 발견되면 적절한 구조물의 보강을 통해 교정되어야 한다. ${ }^{5,716)}$ 보조적인 술식을 사용하여도 만곡이 심한 경우 또는 술전에 연골의 기형이 심 하다고 판단되는 경우는 연골의 전체 또는 전방부위를 모두 제 거하여 체외교정술을 시행한 후 다시 재이식하고 고정한다.

Tips

1) 연골부의 교정은 수술장에서 봉합 또는 보강이식술을 하여 바르게 교정하여야 한다.

2) 수술장에서 연골 또는 골부 중격이 원하는 만큼 바르게 교정된 것을 확인해야 장기적인 좋은 결과를 보장할 수 있다.

3) $\mathrm{L}$ 구조물의 보존은 매우 중요하며 적절한 너비를 보존하 였더라도 두께가 얇은 경우는 보강을 해준다.

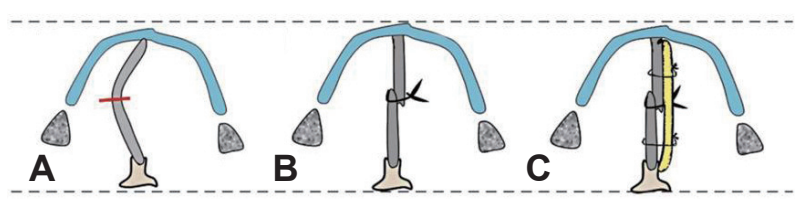

Fig. 7. Illustration of the cutting and suture technique. The deviated caudal L-strut was cut at the most curved portion in the caudocephalic direction (A). The excess portions of the upper and lower caudal strut were then laid over each other, and the overlapping cartilages were secured in place with 3 to 4 stitches using 5-0 polydioxanone sutures (B). If the stability of the newly created caudal septum was questionable, a septal batten graft made from cartilage removed from the central part was placed for further support (C). Adapted from Jang, et al. ${ }^{15)}$ Arch Otolaryngol Head Neck Surg 2009;135(12): $1256-60$. 
4) 연골을 곧게 펴서 전상악극에 긴장 없이 편안하게 놓여질 수 있는 미부의 길이 계측과 고정은 매우 중요하다.

5) 수술 전에 비 배부의 상태를 기술해 놓는 것이 술 후 변형 에 대한 근거로 사용할 수 있으므로, 작은 함몰 또는 비혹에 대 한 상태를 인지하고 기록에 남겨두는 것이 좋다.

\section{비중격 체외교정술(Extracorporeal septoplasty, ECS)}

비중격 체외교정술(Extracorporeal septoplasty)은 수술장 내 다른 테이블에서 완벽한 시야하에 새로운 비중격 neoseptum을 만드는 술식으로 좁은 시야하에서 보존적으로 비중격 교정술을 시행하는 것보다 한편으로는 더욱 편하고 좋은 결과 를 보여주며 외상 후 또는 이차수술로 인해 비중격의 변형이 매우 심한 경우 적응증이 된다.

초기에 소개된 수술방법은 다음과 같다. 비중격 구조 전체 를 제거한 후 잉여연골과 골절부위의 섬유화된 부위를 제거하 고 서로 봉합하는데, 연골의 변형부위에는 칼집을 내어 약화 시키고, 골부는 드릴을 이용하여 편평하게 해준다. 이후 다듬어 진 얇은 골부를 약해진 연골부위에 덧대어 봉합해 주고 비 배 부의 만곡에는 펼침이식술을 시행한다. 경우에 따라 PDS 포일 에 연골조각들을 지지대로 사용하여 연결해주고 원래의 위치 에 배치를 하는데 원래의 비중격 배열에서 최대의 배부와 미 부의 지지를 위해 각을 돌려 이식하기도 한다. 마지막으로 새 로운 비중격을 외비연골에 고정하고 미부는 상악골 극에 단 단히 고정한다. ${ }^{17,18)}$

이후 weak triangle에서의 문제점이 대두되어 Most 변형술 이 도입되었는데, 먼저 변형된 전방의 연골부만을 제거함으로 서 keystone 영역의 불안정을 피하고, 비 배부의 윤곽을 보존 한다. 이후 술식은 유사하여 변형된 연골부의 교정을 시행하 고 연골 조각을 서로 봉합하여 교정된 새로운 비중격을 고정 시키는데, 이는 초기에 보존된 연골의 최상부 또는 비골에 단 단히 고정시키게 된다. ${ }^{19,20)}$

저자는 미부연골의 변형이 심하거나 매우 약하여 적절한 지 지가 힘들 때는 상부의 가능한 지지구조는 최대한 보존하고 연골을 제거하며 후방의 단단한 연골부를 다듬어 새로운 L 구 조를 만들어 상부와 전상악 극에 단단히 고정하는 방법을 시 행한다(Fig. 8).

\section{Tips}

1) 변형된 전체 또는 비중격 전방의 일부를 제거한 후 여러 가지 방법을 이용하여 다른 테이블에서 비중격을 곧게 다듬어 재이식하는 방법이다.

2) 비 폐색이 있으면서 사비변형과 같은 외비변형이 동반되 어 있는 경우 적응증이 될 수 있다.

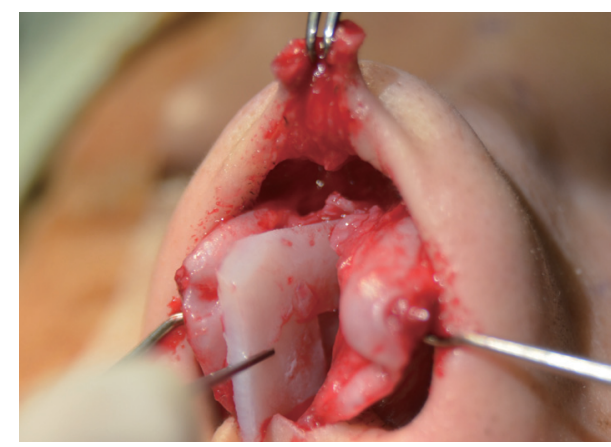

Fig. 8. A newly created $L$ strut cartilage is introduced into the caudal septum and secured at two points, anterior maxillary spine and upper remnant septal cartilage.

3) 사골의 수직판 또는 펼침이식을 비중격 연골부에 봉합 한다.

4) 후 외상성으로 다발성 골절된 비중격의 교정시, 분쇄된 조 각을 $\mathrm{PDS}$ foil에 감싸서 봉합하여 교정에 이용되기도 한다.

5) 비강내 좁은 시야가 아닌 다른 테이블에서 좋은 시야하 에 비중격을 새로 만들고 이를 다시 재 이식할 수 있는 장점은 있으나, 많은 시간이 소요되고, 감염에 유의해야 하고, 이를 재 이식시에 단단한 고정(2 point fixation)이 반드시 필요하다.

\section{고정(Fixation)}

연골의 미부 하연은 교정이 끝난 후 전 상악극에 PDS 봉합 사를 이용하여 고정하는데, 골막이 존재하고 단단히 붙어있으 면 골막에 고정하고, 골막이 부족할 때에는 towel clips나 드릴 로 전상악극에 구멍을 내어 단단히 고정하게 된다. Keystone 부위는 수술시 분리되지 않도록 세밀한 주의를 요하고 분리시 에는 적절히 고정해 주어야 한다. 적절한 연골과 골부의 교정이 이루어지면 절개창은 4-0 chromic catgut 봉합사 등을 이용 하여 닫아준다. 이때도 세심히 봉합하여 술 후 외 비밸브에 부 적절한 반흔이 생기지 않도록 유의해야 한다. 술 중에 손상된 점막은 angled needle holder를 이용하여 4-0 또는 5-0 chromic catgut 봉합사로 닫아주는데 술 후 혈종의 배액을 위하여 편측에만 생긴 점막손상은 그대로 두는 경우도 있고, 의도적으 로 하연에 절개창을 내어 술후 배액을 유도하기도 한다(Fig. 9). 술 후 silastic 부목은 비중격의 지지, 점막치유 유도, 혈종 방지 등의 장점이 있으며, 특히 중요한 점은 습기를 유지하여 수술점막이 마르지 않도록 해준다는 이점이 있어서 술 후 약 1 주일간 유치해둔다.

술 후 비강 패킹의 필요성은 비중격의 안정화, 출혈 및 혈종, 점막유착의 방지를 위하여 시행되나, 술 후 합병증이 더 적거 나 또는 더 나은 술 후 결과를 지지할 근거는 없으며, 술 후 통증 에 관련돼서는 오히려 정도가 더욱 크다. 비강 패킹과 동시에 비중격 부목을 시행하면 술 후 통증은 좀 더 심하고, 보존적인 


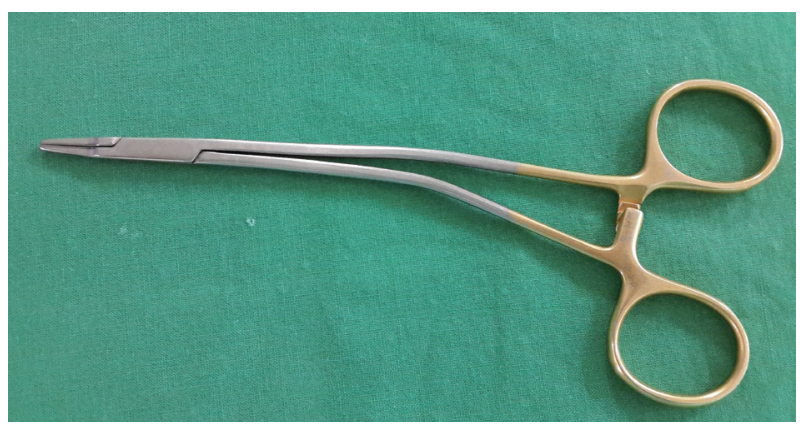

Fig. 9. An angled needle holder is very useful to repair the posterior septal mucosa or performing a quilting suture.

비중격 quilting 봉합술과 술 후 비강세척과 비교할 때 술 후 합 병증이 더 적거나 술 후 결과가 더 나쁜 것으로 나타났다. 그러므 로 술 후 패킹과 부목은 술 후 합병증이 높을 것으로 생각되는 환자에서만 보존적으로 시행되어야 할 것으로 생각된다. ${ }^{21,22)}$

\section{비중격 교정술의 핵심}

1) 비밸브의 문제점을 놓치지 말자(Don't miss the nasal valve).

2) 비 배부의 만곡을 놓치지 말자(Don't miss the dorsal deviation).

3) 복합적인 변형은 체외교정술로 교정하자(Complex deformities may require explantation).

4) 비중격 봉합술로 비강 패킹은 피하자(Septal suturing-no packing needed).

5) 술 후 비배부함몰은 이식술로 교정하자(Dorsal onlay to correct subtle "saddling").

\section{비중격 만곡증을 성공적으로 교정하기 위한 Brennan과 Parkes의 제안 ${ }^{23}$}

1) 수술부위를 충분히 노출시키고 최적의 시야하에 시행 (good exposure)

2) 정확하고 적절한 수술면을 조심스럽게 거상(safe elevation of flaps)

3) 가능한 최소부위의 비중격을 절제(resection of only a limited, necessary amount of septum)

4) 연골탄성 및 골부의 동적인 원인인자의 개선(elimination of etiological dynamic force)

\section{요 약}

비중격 교정술은 과거에 행해지던 만곡부위의 단순한 절제 로부터 시작하여 현대의 개념은 원인인자의 교정 및 적극적인 이식술과 봉합을 통해 수술장에서 바르게 펴진 비중격을 확
인하는 단계로 발전해 왔다. 비중격 만곡증은 비폐색감을 유 발하는 많은 원인들 중의 하나로 이의 교정이 환자의 주관적 증세와 삶의 질을 높이는 술식임에는 이론이 없지만, 다양한 변형에 따른 교정술을 숙지하고, 정확한 수술면을 통해 수술 을 시행하여야 한다. 수술 전에 반드시 수술의 목적과 결과에 대해 환자와 충분한 상담을 시행하고, 동적인 비폐색을 유발하 는 인자와 미용적인 문제에 대해서도 주의를 기울여야 한다.

\section{REFERENCES}

1) Gillman GS, Egloff AM, Rivera-Serrano CM. Revision septoplasty: a prospective disease-specific outcome study. Laryngoscope 2014; 124(6):1290-5.

2) Koo SK, Choi JW, Kim YJ, Kim YJ. Retrospective analysis of endoscopic septoplasty. Korean J Otorhinolaryngol-Head Neck Surg 2012;55(9):559-64.

3) Lee J, White WM, Constantinides M. Surgical and nonsurgical treatments of the nasal valves. Otolaryngol Clin North Am 2009;42 (3):495-511.

4) Jin HR, Won TB. Septoplasty; Current concept and technique. J Rhinol 2008;15(1):13-29.

5) Simon P, Sidle D. Augmenting the nasal airway: beyond septoplasty. Am J Rhinol Allergy 2012;26(4):326-31.

6) Cho JH, Han SY, Kim TH, Kim DE, Ahn BH. The footplate suture technique for external nasal valve surgery. J Rhinol 2014;21(1):41-3.

7) Dobratz EJ, Park SS. Septoplasty pearls. Otolaryngol Clin North Am 2009;42(3):527-37.

8) Guyuron B, Uzzo CD, Scull H. A practical classification of septonasal deviation and an effective guide to septal surgery. Plast Reconstr Surg 1999;104(7):2202-9; discussion 2210-2.

9) Fettman N, Sanford T, Sindwani R. Surgical management of the deviated septum: techniques in septoplasty. Otolaryngol Clin North Am 2009;42(2):241-52, viii.

10) Lee JE, Jung HJ, Chang M, Jin HR. A novel wedge technique to correct the curved deviation of the cartilaginous nasal septum. Auris Nasus Larynx 2014;41(2):190-4.

11) Song SH, Nam WH, Kim JS. Anchoring suture for correction of septal deviation. J Rhinol 2006;13(1):18-21.

12) Kang JM, Nam ME, Dhong HJ, Kim HY, Chung SK, Kim JH. Modified mattress suturing technique for correcting the septal high dorsal deviation around the keystone area. Am J Rhinol Allergy 2012;26(3): 227-32.

13) Wee JH, Lee JE, Cho SW, Jin HR. Septal batten graft to correct cartilaginous deformities in endonasal septoplasty. Arch Otolaryngol Head Neck Surg 2012;138(5):457-61.

14) Chung YS, Seol JH, Choi JM, Shin DH, Kim YW, Cho JH, et al. How to resolve the caudal septal deviation? Clinical outcomes after septoplasty with bony batten grafting. Laryngoscope 2014;124(8): 1771-6.

15) Jang YJ, Yeo NK, Wang JH. Cutting and suture technique of the caudal septal cartilage for the management of caudal septal deviation. Arch Otolaryngol Head Neck Surg 2009;135(12):1256-60.

16) Daniel RK, Brenner KA. Saddle nose deformity: a new classification and treatment. Facial Plast Surg Clin North Am 2006;14(4):301-12, vi.

17) Gubisch W, Constantinescu MA. Refinements in extracorporal septoplasty. Plast Reconstr Surg 1999;104(4):1131-9; discussion 1140-2.

18) Gubisch W. Extracorporeal septoplasty for the markedly deviated septum. Arch Facial Plast Surg 2005;7(4):218-26.

19) Wilson MA, Mobley SR. Extracorporeal septoplasty: complications and new techniques. Arch Facial Plast Surg 2011;13(2):85-90.

20) Persichetti P, Toto V, Marangi GF, Poccia I. Extracorporeal septoplasty: 
functional results of a modified technique. Ann Plast Surg 2012;69 (3):232-9.

21) Quinn JG, Bonaparte JP, Kilty SJ. Postoperative management in the prevention of complications after septoplasty: a systematic review. Laryngoscope 2013;123(6):1328-33.
22) Dubin MR, Pletcher SD. Postoperative packing after septoplasty: is it necessary? Otolaryngol Clin North Am 2009;42(2):279-85, viii-ix.

23) Brennan HG, Parkes ML. Septal surgery: the high septal transfixion. Int Surg 1973;58(10):732-4. 